\title{
Старостина А.Н. \\ ЕГЭ, как современная форма проверки знаний, достоинства и недостатки
}

ГБОУ ВО Нижегородский государственный инженерно - экономический университет

(Россия, Княгинино)

doi: 10.18411/lj-07-2021-155

\section{Аннотация}

Положительные и негативные стороны единого государственного экзамена обсуждаются уже не один год. Для многих людей - это буквально спасение, для других попытка осложнить жизнь ученикам. Как правило, больше всего недовольства высказывают приверженцы советской системы - родители, учителя и преподаватели вузов. Молодое поколение в своем большинстве радуется ЕГЭ, ведь оно не только упрощает поступление в любую точку страны, но и намного проще в плане подготовки. Противоречивые мнения вызывают много сомнений, что и приводит к необходимости разобраться в ЕГЭ.

Ключевые слова: единый государственный экзамен, критерии оценивания, способности ученика.

\section{Abstract}

The positive and negative aspects of the unified state exam have been discussed for more than one year. For many people, this is literally a salvation, for others, an attempt to complicate the life of students. As a rule, most of the dissatisfaction is expressed by adherents of the Soviet system - parents, teachers and university teachers. The younger generation is mostly happy with the Unified State Exam, because it not only simplifies admission to any place in the country, but also much easier in terms of preparation. Conflicting opinions raise a lot of doubts, which leads to the need to understand the Unified State Exam.

Keywords: unified state exam, assessment criteria, student's abilities.

Еди́ный госуда́рственный экза́мен (ЕГЭ) — централизованно проводимый в Российской Федерации экзамен в средних учебных заведениях - школах и лицеях. Служит одновременно выпускным экзаменом из школы и вступительным экзаменом в вузы. При проведении экзамена на всей территории России применяются однотипные задания и единые методы оценки качества выполнения работ. После сдачи экзамена всем участникам выдаются свидетельства о результатах ЕГЭ (в быту нередко называемые сертификатами), где указаны полученные баллы по предметам. С 2009 года ЕГЭ является единственной формой выпускных экзаменов в школе и основной формой вступительных экзаменов в вузы, при этом есть возможность повторной сдачи ЕГЭ в последующие годы. ЕГЭ проводится по русскому языку, математике, иностранным языкам (английскому, немецкому, французскому, испанскому), физике, химии, биологии, географии, литературе, истории, обществознанию, информатике $\mathrm{e}^{[1][2][3] .}$

Организатором ЕГЭ является Владимир Хлебников ${ }^{[4]}$. Впервые эксперимент по введению ЕГЭ был проведён в 2001 в республиках Чувашия, Марий Эл, Якутия, а также в Самарской и Ростовской областях по восьми учебным дисциплинам ${ }^{[5]}$. В 2002 году эксперимент по введению единого государственного экзамена прошел в 16 регионах страны ${ }^{[6]}$. В 2003 году эксперимент охватил 47 субъектов РФ, а в $2004-65$ регионов страны ${ }^{[7]}$. В 2006 ЕГЭ уже сдавали около 950 тысяч школьников в 79 регионах России. В 2008 его сдавали свыше миллиона учащихся во всех регионах. Конкретный перечень предметов, по которым ЕГЭ проводился в 2001-2008 годах, устанавливался каждым регионом самостоятельно. В 2009 году поступление в вузы осуществляется преимущественно по результатам ЕГЭ (за исключением военных специальностей и 
специальностей, связанных с государственной тайной) ${ }^{[8]}$. Для поступления в вуз абитуриенту необходимо сдать вступительные экзамены в форме ЕГЭ. Список вступительных экзаменов утверждается Министерством образования и науки ${ }^{[9]}$ и содержит, как правило, четыре экзамена для каждой специальности (в некоторых случаях - три). Для каждой специальности один из экзаменов является профильным (в перечне профильный экзамен выделен). Вуз может сократить количество экзаменов до трёх, в число экзаменов обязательно должен входить экзамен по русскому языку и профильному предмету. Результаты ЕГЭ действительны до 31 декабря года, следующего за годом выпуска, то есть свидетельство о ЕГЭ образца 2009 года действительно до 31 декабря 2010 года ${ }^{[10]}$. Лица, получившие свидетельство о результатах ЕГЭ и призванные в том же году в Вооружённые Силы РФ, имеют право использовать результаты ЕГЭ в течение года с момента увольнения с военной службы. При приёме на специальности, предполагающие наличие у абитуриентов определённых творческих способностей, физических или психологических качеств вузы также проводят дополнительный экзамен или творческий конкурс, кроме трёх экзаменов, проводимых в форме ЕГЭ. Перечень таких специальностей утверждается Министерством образования и науки ${ }^{[11]}$. Избранным вузам разрешается проводить дополнительные профильные экзамены. Перечень вузов, которым разрешено проводить дополнительные вступительные испытания и порядок их проведения определяется Правительством РФ ${ }^{[12]}$. В 2009 году дополнительные вступительные экзамены профильной направленности по отдельным специальностям получили право проводить 24 вуза ${ }^{[13]}$. Без вступительных испытаний могут приниматься в вуз победители и призёры заключительного этапа Всероссийской олимпиады школьников ${ }^{[14]}$. Также, победители и призёры олимпиад школьников из числа утверждённых Министерством образования и науки ${ }^{[15]}$ могут приниматься в вуз без вступительных испытаний или без сдачи дополнительного вступительного испытания профильной направленности, если таковое имеется ${ }^{[16]}$. На специальности, связанные с физкультурой и спортом, без экзаменов принимаются чемпионы Олимпийских игр. Предполагается, что введение ЕГЭ упростит поступление в вузы для абитуриентов из сельской местности и удалённых регионов. Абитуриент сможет подать заявление в выбранный вуз и приложить к нему информацию о сдаче ЕГЭ заочно - по почте или через интернет, не приезжая лично в выбранный вуз. При этом можно подать заявление в несколько вузов. Вузы могут проверить информацию о результатах сдачи ЕГЭ в Федеральной базе свидетельств о результатах ЕГЭ. В 2009 году у абитуриентов появилась возможность поступать по результатам единого государственного экзамена сразу в несколько вузов. Это вызвало значительный наплыв абитуриентов, что стало причиной внедрения трёхступенчатой корректировки списка поступающих (итоговые проходные баллы в каждом вузе поэтапно снижались за счёт выбывания тех абитуриентов, кто выбрал другой вуз).

Существует положительная сторона ЕГЭ :

Доводы в пользу ЕГЭ:

1. ЕГЭ помогает избежать коррупции и блата при поступлении в ВУЗы. ${ }^{[17][18]}$

2. ЕГЭ оценивает знания и способности ученика более объективно, чем традиционные виды экзаменов ${ }^{[19]}$.

3. ЕГЭ стимулирует подготовку учеников к экзамену, в том числе и самостоятельную ${ }^{[20]}$.

4. ЕГЭ позволяет сравнивать качество образования в разных школах и регионах. 
5. ЕГЭ позволяет выпускникам поступать в вузы, находящиеся на значительном расстоянии от места их проживания, не тратясь на дорогу, а всего лишь отправив сведения о сдаче ЕГЭ по почте. Облегчается подача документов сразу в несколько вузов, без необходимости сдавать в каждом из них экзамены. ${ }^{[17]}$

6. ЕГЭ позволяет выявлять достойных абитуриентов в провинции, которые ранее не имели возможности сдавать вступительные экзамены в крупных городах. ${ }^{[17]}$

7. Проверка результата частично компьютеризирована, что позволяет сэкономить время и деньги, так как не надо тратиться на услуги наёмных проверяющих.

8. Повышение требований на ЕГЭ, как утверждается, ведёт к повышению качества образования, квалификации учителей и качества учебной литературы.

9. ЕГЭ похож на системы выпускных экзаменов в развитых странах (США, Израиль и другие), что со временем может привести к признанию российских школьных аттестатов в других странах.

10. ЕГЭ оценивается по более широкой шкале баллов (100), нежели стандартные экзамены (фактически 4), что делает возможным выявлять лучших из лучших.

ЕГЭ:

Но также существует отрицательная позиция введения в систему образования

\section{Доводы против ЕГЭ:}

1. Контрольно-измерительные материалы ${ }^{[21]}$ непривычны для российской системы образования.

2. Выбор одного варианта из нескольких не всегда показывает реальных знаний учащегося, так как часть ответов может быть выбрана случайно. Тестовая форма главным образом показывает качество выученного материал и плохо пригодна для оценки компетентности или способности к творческому подходу.

3. В ЕГЭ по обществознанию ${ }^{[22]}$ содержатся некорректно поставленные задания и спорные варианты ответов.

4. ЕГЭ не помогает полностью избежать коррупции ${ }^{[23]}$.

5. Нельзя одним контрольно-измерительным материалом качественно проверить уровень подготовленности слабо и хорошо подготовленных выпускников школ.

6. Не учитывается специализация школы: ученики как школ с гуманитарным, так и с естественно-научным уклоном сдают один и тот же вариант обязательного выпускного экзамена.

7. ЕГЭ приводит к новому виду репетиторства, связанного с повышением уровня знаний в спецификациях ЕГЭ. ${ }^{[17]}$

8. Повышение уровня конкуренции в вузах за счет иногородних абитуриентов.

9. При компьютеризированной проверке частей А и В возможны ошибки распознавания ответов ученика, которые засчитываются как неправильные ответы.

10. Запугивание учеников начинается, чуть ли не с первых лет обучения в старшей школе. Не только учителя, но и родители разглагольствуют на тему сложности и невозможности сдачи ЕГЭ. На деле этот единый государственный экзамен куда проще обычных экзаменов или хотя бы 
не сложнее их. Да, предупреждать нужно, но запугивание скорее усложняет обучение, чем его налаживает.

11. Отмена устной части экзамена ухудшает качество подготовки к экзаменам и качество знаний абитуриентов.

Единый государственный экзамен во многом упрощает поступление, расширяет возможности простых сельских абитуриентов, которые стараются получить образование, и сужает возможности богатеев, желающих заполучить корочку без элементарных знаний.

Конечно, у всего есть недостатки, и эта система не идеальна. Многие жалуются, что школьные оценки и обучение становится бессмысленными. Медали, награды, да и сам аттестат теряет свою ценность. Но на деле это не совсем так. Часто при поступлении возникают спорные случаи, когда на одно место претендуют два человека с одинаковыми балами ЕГЭ. В этом случае и идут в ход аттестаты и награды. Ученика с большим потенциалом и зачисляют в вуз.

$$
* * *
$$

1. Федеральный закон № 17-Ф3 от 09.02.2007 о введении ЕГЭ

2. Приказ Рособрнадзора № 74 от 19.01.2009 «Об утверждении сроков и единого расписания проведения ЕГЭ... в 2009 году»

3. Порядок проведения ЕГЭ в 2009 году

4. Учёный, создавший технологию ЕГЭ, ответил на ваши вопросы в прямом эфире из редакции «Новой», Новая газета. Проверено 28 июня 2010.

5. Е.В.Мишукова Единый государственный экзамен. Идея, сущность, принципы (рус.). bank.orenipk.ru (декабрь 2001). Проверено 22 мая 2010.

6. Более половины школьников будут сдавать единый госэкзамен, Страна.RU (8 октября 2002). Проверено 22 мая 2010.

7. ЕГЭ не может расцениваться в качестве единственного критерия, Российский общеобразовательный портал (18 октября 2004). Проверено 22 мая 2010.

8. Порядок приёма граждан в государственные и муниципальные образовательные учреждения высшего профессионального образования на 2009/2010 учебный год

9. Перечень вступительных испытаний в 2009 году в образовательные учреждения высшего профессионального образования, имеющие государственную аккредитацию

10. Основные сведения о ЕГЭ

11. Перечень специальностей при приёме на которые могут проводиться дополнительные вступительные испытания творческой или профессиональной направленности

12. Постановление Правительства Российской Федерации от 23 апреля 2008 г. № 294 «Об утверждении Правил отбора государственных образовательных учреждений высшего профессионального образования, которым предоставляется право проводить дополнительные вступительные испытания профильной направленности»

13. Распоряжение Правительства Российской Федерации от 24 декабря 2008 года № 1921-р, устанавливающее перечень вузов и и специальностей, на которые проводятся дополнительные профильные вступительные экзамены

14. Положение о Всероссийской олимпиаде школьников

15. Перечень олимпиад школьников на 2008-2009 учебный год

16. Порядок проведения олимпиад школьников

17. 1234 Лев Сирин. Андрей Фурсенко: «ЕГЭ уменьшил взятки».. Фонтанка.ру (26 октября 2009).

18. Мария Кривовяз, Татьяна Ткачева, Элина Труханова. Вузы Центральной России подождут абитуриентов до конца августа., Российская газета (27 августа 2009 года). Проверено 4 июня 2010.

19. Четверть учащихся, сдававших единый государственный экзамен получили "двойки" по литературе и математике.. Российская газета (17 июня 2008). Проверено 4 июня 2010.

20. Что надо знать о ЕГЭ.. pedsovet.su (1 февраля 2009).

21. КИМ - Контрольно-измерительный материал, он же - набор тестовых заданий (часть А, В) и заданий с развёрнутым ответом (часть С)..

22. Ольга Андреева, Григорий Тарасевич. В такой «общаге» жить опасно. Журнал «Скепсис». Проверено 11 января 2010.

23. Ђ-Деньги - Экзамен на коррупцию (Проверено 24 мая 2009) 